\title{
Effect of Moderate Intensity Exercise on Body Weight and Blood Estrogen Level Ovariectomized Mice
}

\author{
Rizka Eka Prasetya, ${ }^{1}$ Sri Umijati, ${ }^{2}$ Purwo Sri Rejeki, ${ }^{3,4,5 *}$ \\ ${ }^{1}$ Faculty of Medicine Universitas Airlangga Surabaya, Indonesia, ${ }^{2}$ Department of Public Health and Preventive \\ Medicine Faculty of Medicine Universitas Airlangga Surabaya, Indonesia, ${ }^{3}$ Department of Physiology Faculty of \\ Medicine Universitas Airlangga Surabaya, Indonesia, ${ }^{4}$ Health Science Sport Master Program, Faculty of Medicine \\ Universitas Airlangga Surabaya, Indonesia, ${ }^{5}$ Basic Medical Science Master Program, Faculty of Medicine \\ Universitas Airlangga Surabaya, Indonesia
}

\begin{abstract}
Estrogen is a hormone which is related to lipid oxidation, lypogenesis inhibition, and lipolysis rate. The purpose of this study was to determine the effect of moderate intensity exercise on body weight and blood estrogen level in ovarectomized mice (ovx). The study was held in the Laboratory of Biochemistry, Faculty of Medicine Universitas Airlangga during the period of April to May 2017 on old nineteen 3-4 months old female mice, , 20-30 grams of weight, which were divided into two groups: $\operatorname{OVX}(n=9$, ovx without exercise $)$ and $\operatorname{OVX}+\mathrm{E}(\mathrm{n}=10$, ovx and moderate intensity exercise). Moderate intensity exercise in this study included swimming, three times a week at $3 \mathrm{pm}$ for four weeks using a $6 \%$ of body weight load. Experiment data were analyzed by paired t-test and independent t-test using SPSS. The average body weights of the OVX group were $26.44 \pm 1.94$ grams and $29.89 \pm 2.62$ gram at pretest and posttest, respectively., while for the OVX+E group, the weights were $26.50 \pm 2.59$ grams and $26.40 \pm$ 2.07 grams. There were asignificant intergroup body weight differences $(\Delta \mathrm{OVX}=3.44 \pm 2.55$ gram and $\Delta \mathrm{OVX}+\mathrm{E}=$ $-1.00 \pm 1.37$ gram $)$ with $p=0.004$. Blood estrogen level in $\mathrm{OVX}+\mathrm{E}(12.04 \pm 10.13 \mathrm{ng} / \mathrm{ml})$ was higher than in control $(\mathrm{OVX}=11.24 \pm 8.33 \mathrm{ng} / \mathrm{ml})$; however, the difference was not significant $(\mathrm{p}=0.855)$. Moderate intensity exercise reduces body weight, without any significant increase in blood estrogen level. Hence, the body weight loss is not caused by estrogen, which may be due to the short period of exercise in this study that the estrogen has not had the time to increase.
\end{abstract}

Key words: Blood estrogen level, exercise, moderate intensity, ovariectomy, obesity

\section{Pengaruh Olahraga Intensitas Sedang terhadap Berat Badan dan Kadar Estrogen Darah pada Mencit Ovariektomi}

\begin{abstract}
Abstrak
Estrogen merupakan hormon yang berperan pada oksidasi lipid, kecepatan lipolisis, dan hambatan lipogenesis. Penelitian bertujuan mengetahui pengaruh olahraga intensitas sedang terhadap berat badan dan kadar estrogen darah pada mencit ovariektomi (ovx). Penelitian dilaksanakan di Laboratorium Biokimia Fakultas Kedokteran Universitas Airlangga, April-Mei 2017. Sejumlah 19 mencit betina berusia 3-4 bulan, berat 20-30 gram, dibagi menjadi dua kelompok: OVX ( $\mathrm{n}=9$, ovx tanpa perlakuan) dan OVX+E $(\mathrm{n}=10$, ovx dengan olahraga intensitas sedang). Olahraga intensitas sedang dilakukan dengan renang, tiga kali seminggu pukul 15.00 WIB selama empat minggu dengan beban $6 \%$ dari berat badan. Data dianalisis dengan paired t-test dan independent $t$-test SPSS.

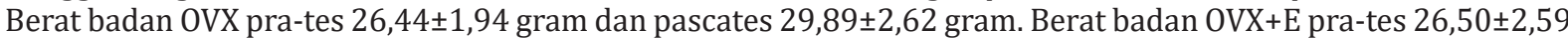
gram dan pascates $26,40 \pm 2,07$. Terdapat perbedaan bermakna berat badan antarkelompok $(\Delta \mathrm{OVX}=3,44 \pm 2,55$ gram and $\Delta \mathrm{OVX}+\mathrm{E}=-1,00 \pm 1,37$ gram), $\mathrm{p}=0,004$. Kadar estrogen darah $\mathrm{OVX}+\mathrm{E}(12,04 \pm 10,13 \mathrm{ng} / \mathrm{mL})$ lebih tinggi daripada konrol $(\mathrm{OVX}=11,24 \pm 8,33 \mathrm{ng} / \mathrm{mL})$, tetapi tidak berbeda bermakna $(\mathrm{p}=0,855)$. Olahraga intensitas sedang menurunkan berat badan, tetapi tidak bermakna meningkatkan kadar estrogen darah. Penurunan berat badan tidak disebabkan oleh estrogen. Peningkatan estrogen belum terjadi mungin disebabkan oleh waktu yang kurang lama.
\end{abstract}

Kata kunci: Kadar estrogen darah, obesitas, olahraga intensitas sedang, ovariektomi

Korespondensi: Dr. Purwo Sri Rejeki, dr., M.Kes, Department of Physiology, Faculty of Medicine Universitas Airlangga. Jalan Prof. Dr. Moestopo No. 47, Surabaya Tlp: (031)5023621, Email: purwo_faal@yahoo.com; purwo-s-r@fk.unair.ac.id 


\section{Introduction}

Overweight and obese Indonesian population over 18 years old increased from year to year. It's prevalence in 2013 has reached 28.9\% of the adult population. ${ }^{4}$ Obesity is found in postmenopausal women. ${ }^{1}$ Visceral fat is increased by $30 \%$ in postmenopausal women and related to cardiovascular disease, insulin resistance, and cancer. ${ }^{5}$ Women's obesity often occurs due to low blood estrogen levels ${ }^{6}$ and high body weight. ${ }^{7}$ Estrogen and progestin hormone therapy as a solution and prevention of postmenopausal women's obesity increases breast cancer risk, ${ }^{8}$ so a suitable strategy to prevent obesity of postmenopausal women is needed. In addition to increasing energy output, physical activity can also increase the expression of genes that encode aromatase. Aromatase is an enzyme that plays a role in estrogen hormone synthesis. ${ }^{9}$ Estrogen decreases visceral adipose period by reducing the expression of SREBP and lipoprotein lipase which play a role in lipogenesis ${ }^{3}$.

Swimming with moderate intensity is a good intervention for postmenopausal women, it doesn't have a significant negative impact on the body, ${ }^{10}$ but its effects on estrogen hormone and body weight in postmenopausal women remain unknown clearly. Temporary suspicion is that moderate intensity of swimming affects blood estrogen level and body weight so it can be used as a preliminary strategy to prevent obesity. The purpose of this study was to determine effect of moderate intensity exercise on body weight and blood estrogen level of ovarectomizedmice (ovx).

\section{Methods}

The study was conducted by posttest only control group design approach under the approval of Medical Research Ethics Committee Faculty of Medicine, Universitas Airlangga Surabaya (188/EC/EPK/FKUA/2016). Twenty-six mice (BALB/c) 3-4 mo aged, 20-30 gram were obtained from Animal Models Laboratory of Biochemistry Department, Faculty of Medicine Universitas Airlangga. The study has been held on April-May 2017. Animals were maintained in some cages in the room temperature $25-30^{\circ} \mathrm{C}$, with enough food and drinking water.

Mice were excised by dorsal incision with general anesthesia which are obtained by mixing ketamine $0,5 \mathrm{~mL}$ and xylazine $0.5 \mathrm{~mL}$ in $1 \mathrm{~mL}$ syringe, then intraperitoneal injection was done on mouse $0.05 \mathrm{~mL}$ each. Once anesthetized, the abdominal incision began, the fallopian tube were ligated, and the ovaries were cut and discarded. Open wounds due to incisions were covered with a suture procedure. Mice were given seven days to recover.

The 19 mice were acclimatized for a week and then divided into two groups, which are control group (OVX) and exercise group (OVX+E). In the control group, mice were not given by Moderate Intensity Exercise (MIE) intervention. In other hand, MIE (three times a week for four weeks) was performed to exercise group every 15.00 WIB with load $6 \%$ of body weight that was done by calculating the maximum duration of swimming ability each mouse. Duration of exercise was taken from $80 \%$ of the maximum time achieved by each mouse.

Animal weights were measured in all groups, at four days before ovariectomy, just before ovariectomy, a week after ovariectomy, and every week during exercise using a torbal (torsion balance) scales Camry EK3250 in gram using with precision one digit behind the comma.

In the end of experiment, mice were eventually terminated and their blood samples were taken from the heart. Then blood estrogen level was measured using ELISA method Sigma Aldrich in $\mathrm{pg} / \mathrm{mL}$.

Data were analyzed for distribution normality with Kolmogorov Smirnov test and different test using independent t-test. Comparation between body weight before and after exercise were analyzed using paired $t$ test. Data analysis using SPSS version 17.

\section{Results}

Initial weight until a week after ovariectomy done in each of two groups can be seen in table 1 . The measurement of BW initial (body weight four days before ovariectomy), BW pre-OVX (body weight just before ovariectomy), and BW postOVX (body weight a week after ovariectomy) were homogenous statistically and data were in normal distribution (Table 1). All mice in both control and exercise group 3 mo aged.

After mice were ovariectomized and performed by swimming according to each group, there is a body weight gain in the negative control group, while in exercise group the reduction of body weight was eventually shown.

Figure 1 shows the MIE has the potency in preventing the body weight gain of ovariectomized mice. Body weight OVX (blue 
Rizka E. Prasetya et al.: Effect of Moderate Intensity Exercise on Body Weight and Blood Estrogen Level Ovariectomized Mice

Table 1 Body Weight of Mice Before Exercise

\begin{tabular}{|c|c|c|c|}
\hline Group & $\mathbf{n}$ & Body Weight Before Exercise (gram) & Independent t Test \\
\hline OVX & 9 & $26.44 \pm 1.94$ & \multirow{2}{*}{$\begin{array}{l}\text { Homogenity }=0.415 \\
p=0.959\end{array}$} \\
\hline $\mathrm{OVX}+\mathrm{E}$ & 10 & $26.50 \pm 2.59$ & \\
\hline
\end{tabular}

*OVX is ovariectomized mice without exercise

Table 2 Blood Estrogen Level After Four Weeks Exercise

\begin{tabular}{|c|c|c|c|c|c|}
\hline \multirow{2}{*}{ Group } & \multirow{2}{*}{$\mathbf{N}$} & \multicolumn{3}{|c|}{ Blood Estrogen Level (ng/mL) } & \multirow{2}{*}{ Independent $\mathrm{t}$ Test } \\
\hline & & Mean \pm SD & Min & Max & \\
\hline OVX & 9 & $11.24 \pm 8.33$ & 1.04 & 19.93 & \multirow{2}{*}{$\begin{array}{c}\text { Homogenity }=0.014 ; \\
F=7.439 ; p=0.855\end{array}$} \\
\hline $\mathrm{OVX}+\mathrm{E}$ & 10 & $12.04 \pm 10.13$ & 1.46 & 22.87 & \\
\hline
\end{tabular}

*OVX is ovariectomized mice without exercise; ${ }^{* *} \mathrm{OVX}+\mathrm{E}$ is ovariectomized mice moderate intensity exercise

line) in a first week raise up, then goes down in the second week, but in third week until end of experiment it shows an increasing line again (body weight has significant difference compare to initial point, $p=0.004)$. In the other side, body weight $\mathrm{OVX}+\mathrm{E}$ (orange line) fall until second week, then increase again in the third week till end of experiment without significant difference compare to initial point $(\mathrm{p}=0.823){ }^{*}$ significant difference was noted $(\mathrm{p}<0.05)$ between the control group and the exercise group.

Estrogen level was measured from the blood that was obtained from the mouse heart.
Before taking the blood, intervention of mice in exercise group was stopped to avoid the acute effect of exercise. The result of blood estrogen level in both groups can be shown in table 2 . The measurement of blood estrogen level wasn't homogeny statistically but data was in normal distribution.

The level of estrogen was relatively the same and there is no significant difference between two groups $(\mathrm{p}=0.855)$ although the level in exercise group (12.04 $\pm 10.13 \mathrm{ng} / \mathrm{mL})$ was higher than control $(11.24 \pm 8.33)$.

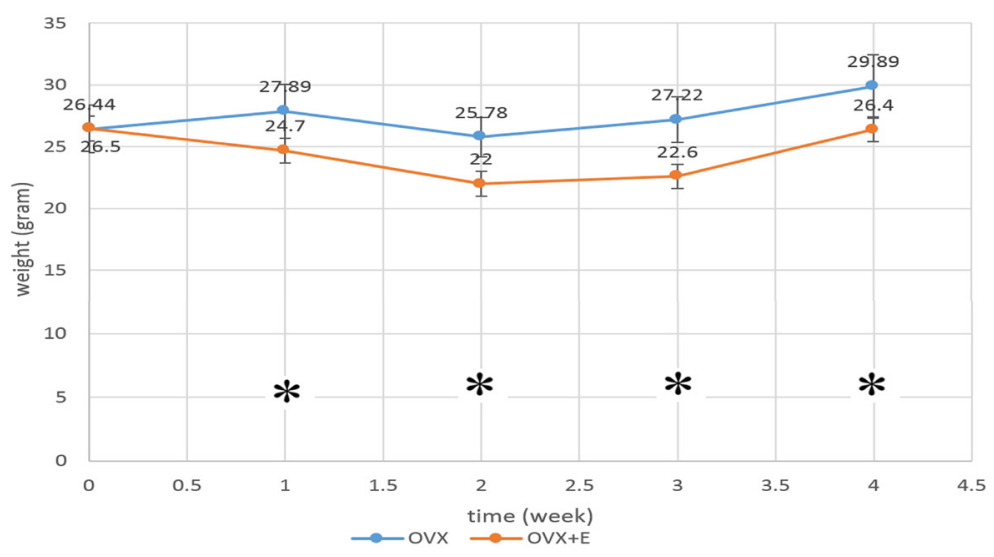

Figure 1 The MIE Has the Potency in Preventing the Body Weight Gain of Ovariectomized Mice

*OVX is ovariectomized mice without exercise; ** OVX+E is ovariectomized mice moderate intensity exercise 


\section{Discussion}

Female mice was chosen to perform ovariectomy which had an intention to represent postmenopausal condition in woman and easily evaluate hormone level as the effect of exercise only (without involvement of estrogen production from ovary). The range of 3-4 mo age was chosen because this range is adult age for mice as the increasing prevalence of obesity in woman.

The physical properties of swimming are good for postmenopausal women because they do not negatively affect bone ${ }^{11}$ and muscle. ${ }^{10}$ Compared to treadmill running and spontaneous wheel exercise, the advantage of swimming is not causing foot injuries, so it may be less physically traumatic to the animal. The Uniform type of physical activity can be found in swimming when applied in appropriate way, there is no "stop and go" activity as that found in treadmill running.

Continuous swimming (mild, moderate to heavy exercise when weights are attached to their tails) produces significant recruitment of both the forelimb and hindlimb muscles, although the pattern of recruitment may differ from that which occurs with treadmill running, based on reduction of glycogen and skeletal muscle blood flow studies. ${ }^{12}$

Moderate intensity exercise using load attached to mice tail has function to set the exercise intensity which result in heart rate as same as human heart rate with the same type of intensity. Body weight is the easiest macro indicator used to evaluate the balance of energy inside our body. The weight gain is found in the negative control with the significant different $(\mathrm{p}<0.05)$.

This finding support the previous research which has successfully proven that exercise would prevent a weight gain in moderate intensity exercise group ovariectomized mice. ${ }^{13}$ Lower weight gain in exercise group than control group also found in result study of 6 weeks moderate intensity exercise ovariectomized mice. ${ }^{14}$

Other finding, that were performed MIE had higher blood estrogen level than control, but analysis independent t-test showed no significant difference $(p>0.05)$. These results support the results of the Bebasari which showed no significant difference serum estrogen levels in ovariectomized rats between control and treadmill group for 8 weeks with frequency 5 times a week. ${ }^{15}$ In the study of Hao et al..$^{16}$ there was a significant increase in serum estrogen levels after treadmill ovariectomized rats compared with ovariectomized rats without intervention.

Different results are caused by differences in exercise type, duration of exercise, and frequency. Research of Hao et al. ${ }^{16}$ used treadmill or running exercise with the same duration from start to finish that was 60 minutes. Treadmill exercise was done in 12 weeks with frequency five times a week. Longer treatment is required more than Bebasari ${ }^{15}$ study or approximately 12 weeks as duration as in Hao et al. ${ }^{16}$ study to make a significant increase blood estrogen levels.

Moderate intensity exercise can prevent weight gain on ovariectomized adult mice. There is no significant difference blood estrogen level between control and exercise group although blood estrogen level exercise group higher than control. Body weight loss in ovariectomized mice was not caused by involvement blood estrogen level for four weeks moderate intensity exercise intervention.

\section{References}

1. Lambrinoudaki I, Brincat $\mathrm{M}$, Erel CT, Gambacciani M, Moen MH, Schenck GK, et al. EMAS position statement: managing obese postmenopausal women. Maturitas. 2010; 66(3):323-6.

2. Sapkota NK, Shah DK, Islam MN. Postmenopausal osteoporosis in obese women. J Biomed Pharmaceutical Res. 2014; 3(6):111-5.

3. D'Eon TM, Souza SC, Aronovitz M, ObinMS, FriedSK, Greenberg AS. Estrogen regulation of adiposity and fuel partitioning evidence of genomic and non-genomic regulation of lipogenicand oxidative pathways. J Biological Chem. 2005;280(43):35983-91.

4. Kementrian Kesehatan RI. Riset kesehatan dasar 2013. Jakarta: Kementrian Kesehatan RI; 2013.

5. Tchernof A, Despres JP. Pathophysiology of human visceral obesity: an update. Physiol Rev. 2013;93(1):359-404.

6. Lizcano F, Guzman G. Estrogen Deficiency and the origin of obesity during menopause. Biomed Res Int. 2014;2014:1-11.

7. Schrager S, Eglash A, Counts H, Redmer J, Slattengren A, Kulie T. Obesity and women's health: an evidence-based review. J Am Board Fam Med. 2011;24(1):75-85.

8. Chlebowski RT, MansonJE, Anderson GL, Cauley JA, Aragaki AK, Stefanick ML, et al. 
Plus progestin and breast cancer incidence and mortality in the women's health initiative observational study. JNCI. 2013;105(8): 526-35.

9. Agustiningsih D, Soejono SK, Soesatyo, Prakosa D. Exercise induce the synthesis of estrogen in ovariectomizessprague-dawley rats ventricular myocardium trough increase expression of CYP19aromatase. Sport Sci Health. 2015;11:337-43.

10. Alkatan M, Baker JR, Machi DR, Park W, Akkari AS, Pasha EP, et al. Improved Function And Reduced Pain After Swimming And Cycling Training In Patients With Osteoarthritis. J Rheumatol. 2016;43(3):666-72.

11. BrutonAG, Agüero AG, Cabello AG, Liorente AM, Casajus JA, Rodriguez GV. The effects of swimming training on bone tissue in adolescence. Scand J Med Sci Sports. 2014;25(6):e589-602.

12. Kregel KC, Allen DL, Booth FW, Fleshner MR, Henriksen EJ, Musch ti, et al. Resource book for the design of animal exercise protocols. Maryland: American Physiological Society; 2006.
13. Marchon C, Ornelas ED, Viegas KA, Laccini $\mathrm{S}$, Souza R, Fonseca FL, et al. Effects of moderate exercise on the biochemical, physiological, morphological and functional parameters of the aorta in the presence of estrogen deprivation and dyslipidemia: an experimental model. Cell Physiol Biochem. 2015;35(1):397-405.

14. Jeong S, Yoon M. Swimming's prevention of ovariectomy-induced obesity through activation of skeletal-muscle PPAR $\alpha$. Int J Sport Nutr Exerc Metab. 2012;22(1):1-10

15. Bebasari E., Pengaruh olahraga teratur terhadap kadar estrogen adiposa dan estrogen serum pada tikus sprague dawley yang dilakukan ovariektomi. Jurnal Ilmu Kedokteran. 2015;9(1):17-21.

16. Hao, Wang Y, Duan Y, Bu S. Effects of treadmill exercise training on liver fat accumulationand estrogen receptor alpha expression in intactand ovariectomized rats with or without estrogenreplacement treatment. Eur J Appl Physiol. 2010;109(5):879-86. 